\title{
Faktor-Faktor yang Mempengaruhi Produksi Usahatani Cabe Rawit Merah di Desa Tapenpah Kecamatan Insana Kabupaten Timor Tengah Utara
}

\author{
Katarina Bete ${ }^{\mathrm{a}}$, dan Werenfridus Taena ${ }^{\mathrm{b}}$ \\ ${ }^{a}$ Fakultas Pertanian, Universitas Timor, Kefamenanu, TTU - NTT, Indonesia. \\ ${ }^{b}$ Fakultas Pertanian, Universitas Timor, Kefamenanu, TTU - NTT, Indonesia.
}

\section{Article Info}

Article history:

Received 8 Desember 2017

Received in revised form 4 Januari 2018

Accepted 8 Januari 2018

\begin{abstract}
Abstrak
Kabupaten Timor Tengah Utara (TTU) merupakan salah satu kabupaten yang memiliki lahan pertanian yang luas dan potensial untuk berusahatani cabe rawit merah. Desa Tapenpah merupakan salah satu desa di wilayah Kecamatan Insana yang masyarakatnya berusahatani cabe rawit merah. Penelitian ini bertujuan untuk mengetahui 1) gambaran usahatani; 2) faktor-faktor yang mempengaruhi produksi; dan 3) Break Event Point (BEP) usahatani cabe rawit merah di desa Tapenpah, kecamatan Insana, kabupaten TTU. Penelitian dilaksanakan di desa Tapenpah, kecamatan Insana, kabupaten TTU pada bulan Apri- Juni 2017. Metode pengambilan data yang digunakan adalah metode survei. Sampel diambil dengan metode sensus, sebanyak 15 orang dijadikan sampel. Untuk mengetahui gambaran usahatani digunakan metode analisis deskriptif kualitatif, untuk mengetahui faktor-faktor yang berpengaruh terhadap produksi usahatani cabe rawit merah digunakan analisis Cobb-Douglas. Selanjutnya juga dihitung Break Event Point (BEP). Hasil penelitian menunjukkan usahatani cabe rawit merah di desa Tapenpah dilakukan secara monokultur dengan luas lahan yang berbeda-beda berkisar antara 9-25 are. Usahatani dilakukan dengan tahapan 1) persiapan berupa pembersihan lahan; 2) pengolahan lahan; 3) benih cabe rawit merah disemaikan; 4) penanaman dilakukan setelah bibit berumur 21 hari; 5) pemeliharaan; 6) panen; dan 7) buah cabe rawit merah disimpan pada tempat yang kering dan sejuk, kemudian cabe rawit merah dijual. Faktor modal, luas lahan, tenaga kerja, pengalaman usahatani, pendidikan petani, dan pupuk kandang secara bersama-sama berpengaruh nyata terhadap produksi cabe rawit merah. Secara parsial faktor pengalaman usahatani, pendidikan petani dan pupuk kandang memiliki pengaruh yang positif, faktor tenaga kerja berpengaruh negatif dan signifikan terhadap produksi usahatani cabe rawit merah. Sedangkan modal dan luas lahan tidak berpengaruh terhadap produksi usahatani cabe rawit merah. Biaya produksi usahatani cabe rawit merah dalam satu kali musim tanam Rp5.530.667,00 dengan harga jual ditingkat petani sebesar Rp60.000,00 per kilogram sehingga BEP rupiah sebesar Rp2.952.602,00 dan BEP unit sebesar $49 \mathrm{~kg}$. (O2018 dipublikasikan oleh Agrimor.
\end{abstract}

\section{Pendahuluan}

Cabe rawit merah (Capsicum frutescens L.) adalah sayuran semusim yang termasuk famili terung-terungan (Solanaceae). Cabe rawit merah merupakan komoditas yang dibudidayakan dalam berbagai skala usaha. Cabe rawit merah juga mengandung zat-zat gizi yang sangat diperlukan untuk kesehatan manusia. Cabe rawit merah dapat dijadikan komoditas pilihan usahatani karena cabe rawit merah memiliki banyak keunggulan, di antaranya memiliki nilai ekonomis yang tinggi, multiguna dalam kehidupan sehari-hari, memiliki wilayah pemasaran yang cukup baik, merupakan komoditas yang dapat dijual dalam berbagai bentuk produk, misalnya cabe segar, cabe beku, dan bermacam produk cabe olahan (Setiadi, 2006).

Kabupaten Timor Tengah Utara (TTU) merupakan salah satu kabupaten yang memiliki lahan pertanian yang luas dan potensial untuk berusahatani cabe rawit merah, tetapi berdasarkan data (BPS Kab. TTU, 2016) produksi cabe rawi merah di kabupaten TTU tahun 2012-2015 mengalami penurunan yakni tahun 2012 sebanyak 66,6 ton, tahun 2013 sebanyak 63,5 ton, tahun 2014 sebanyak 50,8 ton dan tahun 2015 sebanyak 35,5 ton

Desa Tapenpah merupakan salah satu desa di wilayah Kecamatan Insana yang masyarakatnya berusahatani cabe rawit merah. Data pada Profil Desa Tapenpah menunjukkan bahwa produksi cabe rawit merah pada tahun 2012 sebanyak 2,5 ton dengan produktivitas 1,47 t/ha, tahun 2013 produksi 2,97 ton dengan produktivitas 1,75 t/ha, tahun 2014 produksi 2,8 ton dengan produktivitas $1,67 \mathrm{t} / \mathrm{ha}$, dan tahun 2015 produksi 2,3 ton dengan produktivitas $1,35 \mathrm{t} / \mathrm{ha}$ Produktivitas ini masih cukup rendah karena menurut Ajak \& Taolin, (2016) cabe rawit yang ditanam di wilayah kabupaten TTU dapat memberi hasil hingga 4,68 t/ha. Walaupun demikian, menurut Haki \& Taena, (2017) kegiatan usahatan cabe rawit oleh petani di desa Tapenpah layak untuk dikembangkan karena menguntungkan secara ekonomis. Untuk dapat dikembangkan perlu ditentukan strategi pengembangannya, Falo et al., (2016) menyatakan penentuan strateg pengembangan usahatani tentunya petani dituntut untuk memperhatikan faktor eksternal dan internal yang terkait. Selanjutnya menurut Hoar \& Fallo, (2017), faktor sosial ekonomi yang berpengaruh berbeda-beda antara komoditi pertanian yang diusahatanikan maupun faktor sosial ekonomi itu sendiri. Sebagai contoh faktor yang berpengaruh pada produksi usahatani padi sawah di desa Tualene adalah luas lahan dan benih (De Araujo \& Nubatonis, 2016), sedangkan faktor yang mempengaruhi usahatani padi sawah di desa Haekto adalah pupuk, tenaga kerja dan modal (Neonbota \& Kune, 2016). Hal ini berbeda lagi pada komodit sawi yang dipengaruhi oleh luas lahan, bibit, pupuk kandang, dan jumlah tanggungan keluarga (Usboko \& Fallo, 2016).

Produksi cabe rawit merah yang berfluktuasi karena petani tidak dapa mengalokasikan input dengan tepat. Produksi usahatani cabe rawit merah dapat memberikan keuntungan bila secara teknis, produksinya lebih besar dari titik impas, sedangkan harga cabe rawit merah memberikan keuntungan jika harganya lebih besar dari titik impas. Walaupun telah dinyatakan menguntungkan secara ekonomi oleh Haki \& Taena, (2017) tetapi belum dapat dipastikan tentang nilai titik impas dari usahatani cabe rawit merah yang dijalankan. Berdasarkan latar belakang yang ada, maka perlu untuk dilakukan kajian tentang "Faktor-Faktor yang Mempengaruhi Produksi Usahatani Cabe Rawit Merah di Desa Tapenpah, kecamatan Insana, kabupaten TTU" yang bertujuan untuk mengetahui 1) gambaran usahatani cabe rawit merah; 2) faktor-faktor yang mempengaruh produksi usahatani cabe rawit merah; dan 3) Break Event Point (BEP) usahatani cabe rawit merah di desa Tapenpah, kecamatan Insana, kabupaten TTU.

\section{Metode}

Penelitian dilaksanakan di desa Tapenpah, kecamatan Insana, kabupaten TTU pada bulan Apri-Juni 2017. Metode pengambilan data yang digunakan adalah metode survei terhadap data primer dan data sekunder. Data primer adalah data-data yang diperoleh melalui wawancara dengan responden berdasarkan daftar pertanyaan yang disiapkan sebelumnya, sedangkan data sekunder adalah data yang diperoleh dari instansi terkait.

Populasi dalam penelitian ini adalah seluruh petani di desa Tapenpah yang berusahatani cabe rawit merah. Sampel diambil dengan metode sensus dimana semua petani cabe rawit merah sebanyak 15 orang dijadikan sebagai sampel.

Untuk mengetahui gambaran usahatani cabe rawit merah digunakan metode analisis deskriptif kualitatif sesuai panduan Sugiyono, (2006), sedangkan untuk mengetahui faktor-faktor yang berpengaruh terhadap produksi usahatani cabe rawit merah digunakan analisis Cobb-Douglas sesuai petunjuk Gujarati \& Porter, (2009) dengan model Cobb-Douglas dinyatakan oleh hubungan Y dan X, adalah $\mathrm{Y}=\mathrm{f}\left(\mathrm{X}_{1}, \mathrm{X}_{2}, \mathrm{X}_{3}, \mathrm{X}_{4}, \mathrm{X}_{5}, \mathrm{X}_{6}, \mathrm{X}_{7}, \mathrm{X}_{8} \mathrm{X}_{9} \ldots, \mathrm{X}_{\mathrm{i}}\right)$, dimana:

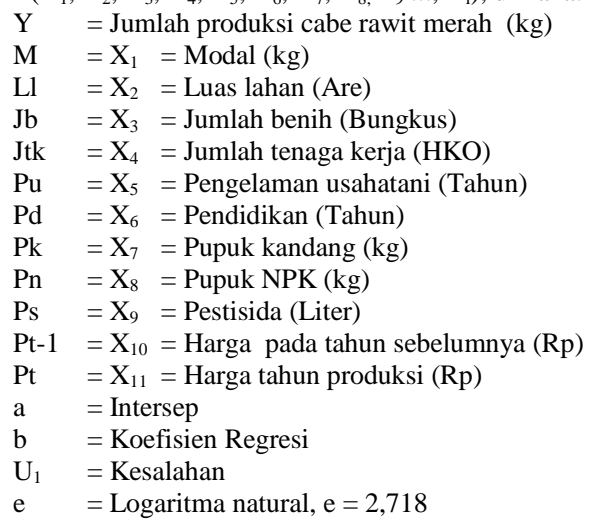

Untuk memudahkan pendugaan terhadap persamaan di atas maka persamaan tersebut diubah menjadi bentuk linear berganda dengan cara melogaritmakan persamaan tersebut. Persamaan di atas dapat ditulis kembali sebagai $\mathrm{Ln} \mathrm{Y}=\mathrm{Ln}$ $\mathrm{a}+\mathrm{b}_{1} \operatorname{Ln} \mathrm{X}_{1}+\mathrm{b}_{2} \operatorname{Ln} \mathrm{X}_{2}+\ldots .+\mathrm{b}_{\mathrm{n}} \mathrm{LnX}_{\mathrm{n}}+$ ei. Untuk mengetahui Break Event Point (BEP) dilakukan analisis sesuai panduan Alwi, (1994). Analisis data dilakukan menggunakan bantuan aplikasi SPSS.16 yang dilakukan sesuai petunjuk Santoso, (2008)

\section{Hasil dan Pembahasan}

\subsection{Gambaran Usahatani Cabe Rawit Merah}

Usahatani cabe rawit merah di lokasi penelitian memiliki luas lahan yang berbeda-beda berkisar antara 9-25 are. Usahatani cabe rawit merah menggunakan pola tanam monokultur. Tahapan usahatani yang dilakukan di lokasi penelitian antara lain persiapan lahan, pengolahan lahan, persiapan bibit, penanaman, pemeliharaan, panen dan pasca panen.

a. Persiapan Lahan

Persiapan lahan di desa Tapenpah untuk budidaya cabe rawit merah meliputi pembersihan lahan dalam hal ini petani membersihkan sisa-sisa rumput menggunakan parang atau tajak agar memudahkan pada saat pengolahan. Awa persiapan lahan pada bulan April. Petani menggunakan tenaga kerja dalam 
keluarga yang berjumlah 25 orang dengan curahan kerja sebesar 21,86 HKO dengan rerata $1,46 \mathrm{HKO}$.

\section{b. Pengolahan Lahan}

Pengolahan lahan yang dilakukan oleh petani di desa Tapenpah dengan cara tanah dicangkul atau dibajak dengan menggunakan pacul atau linggis dengan tujuan untuk menggemburkan tanah sehingga tanaman cabe rawit merah tumbuh dengan baik. Setelah itu dibuat dalam bentuk bedengan dengan lebar bedeng 0,5$1 \mathrm{~m}$, tinggi bedeng $25-40 \mathrm{~cm}$ dan jarak antara bedeng yang satu dengan bedeng yang lainnya 20-30 cm. Jumlah bedeng berkisar 5-10 bedeng. Petani menggunakan tenaga kerja dalam keluarga yang berjumlah 36 orang dengan curahan kerja sebesar 15,43 HKO dengan rerata 2,20 HKO.

\section{c. Persiapan Bibit}

Benih cabe rawit merah yang digunakan oleh petani di desa Tapenpah dibeli di toko pertanian di Kota Kefamenanu. Benih cabe rawit merah disemaikan dalam bedengan yang sudah dicampur dengan pupuk kandang, dan cara persemaiannya ditabur merata ke dalam bedeng secara manual yaitu menggunakan tangan setelah itu disiram dengan air menggunakan ember agar tanah tetap lembap dan basah. Petani menggunakan tenaga kerja dalam keluarga yang berjumlah 35 orang dengan curahan kerja sebesar 12,29 HKO dengan rerata $0,82 \mathrm{HKO}$.

\section{d. Penanaman}

Penanaman yang dilakukan di desa Tapenpah setelah bibit berumur 21 hari dengan kriteria memiliki 3-4 helai daun dan memiliki akar dan batang yang kuat. Bibit cabe rawit merah yang disemaikan dicabut secara manual dan ditanam pada bedengan yang sudah disiapkan menggunakan tugal. Tahapan penanaman dilakukan pada sore hari dengan jarak tanam $60-70 \mathrm{~cm}$, setelah itu dilakukan pemeliharaan yang baik. Petani menggunakan tenaga kerja dalam keluarga yang berjumlah 32 orang dengan curahan kerja sebesar $32 \mathrm{HKO}$ dengan rerata 2,13 HKO.

\section{e. Pemeliharaan}

Pemeliharaan cabe rawit merah yang dilakukan petani di desa Tapenpah dikelompokkan sebagai berikut:

- Penyiraman

Penyiraman yang dilakukan pada pagi hari atau sore hari dengan menggunakan ember. Penyiraman dilakukan secara merata, agar menciptakan kondisi lahan yang tetap lembap dengan tujuan agar mempermudah akar tanaman untuk tumbuh dan berkembang dengan baik. Air diperoleh dari anak sungai. Petani menggunakan tenaga kerja dalam keluarga yang berjumlah 53 orang dengan curahan kerja sebesar $53 \mathrm{HKO}$ dengan rerata 3,53 HKO

o Penyiangan

Penyiangan yang dilakukan di desa Tapenpah yaitu petani membersihkan rumput menggunakan tajak. Penyiangan dilakukan setelah tanaman berumur \pm 2 minggu sesudah penanaman. Petani menggunakan tenaga kerja dalam keluarga yang berjumlah 33 orang dengan curahan kerja sebesar 33 HKO dengan rerata 2,2 HKO.

\section{○ Pemupukan}

Pupuk yang digunakan di desa Tapenpah adalah pupuk kandang dan pupuk NPK. Pemupukan dasar menggunakan pupuk kandang yang diberikan petani pada saat pengolahan tanah, yaitu dengan cara pupuk kandang ditaburkan ke dalam bedengan. Pemupukan kedua dilakukan setelah tanaman cabe rawit merah berumur \pm 3 minggu dengan pemberian pupuk NPK dengan dosis 10-15 g/pohon dengan cara dilarutkan dalam air kemudian disiram per pohon menggunakan ember. Waktu pemupukan dilakukan pada pagi atau sore hari. Petani menggunakan tenaga kerja dalam keluarga yang berjumlah 34 orang dengan curahan kerja sebesar 19,43 HKO dengan rerata 1,30 HKO. Harga pupuk NPK Rp7.000,00/kg, total nilai pupuk sebesar Rp1,547,000,00 dengan rerata biaya pupuk sebesar Rp103,133,33.

○ Pengendalian hama penyakit

Salah satu kendala yang paling ditakuti oleh petani di desa Tapenpah adalah serangan hama penyakit karena akan menyebabkan gagal panen. Serangan hama dan penyakit biasanya menyerang tanaman sejak bibit disemaikan sampai tanaman berproduksi. Sistem pengendalian yang dilakukan petani di lokasi penelitian adalah menggunakan pestisida "Desis Antrapol 70 WP". Desis Antrapol 70 WP digunakan untuk mengendalikan kutu daun. Dosis untuk 1 tangki 14 liter $=5 \times 14=70 \mathrm{ml} / 14 \mathrm{~L}=70 \mathrm{ml} /$ tangki. Waktu penyemprotan dilakukan 1 kali pada pagi atau sore hari. Petani menggunakan tenaga kerja dalam keluarga yang berjumlah 35 orang dengan curahan kerja sebesar $28 \mathrm{HKO}$ dengan rerata 1,87 HKO. Harga pestisida Rp20.000,00/liter total nilai pestisida sebesar Rp380,000,00 dengan rerata biaya pestisida sebesar Rp25.333,00.

\section{f. Panen}

Tanaman cabe rawit merah dipanen pada usia 3-4 bulan setelah masa tanam. Selama masa produktif tanaman yaitu 1,5 tahun, rata-rata cabe rawit merah dapat dipanen sebanyak 30 kali karena pemanenan dilakukan seminggu sekali selama satu tahun. Pemanenan dilakukan secara manual yaitu dipetik menggunakan tangan. Petani menggunakan tenaga kerja dalam keluarga yang berjumlah 45 orang dengan curahan kerja sebesar 45 HKO dengan rerata 3 HKO. Jumlah produksi cabe rawit merah di desa Tapenpah sebesar $4.428 \mathrm{~kg}$, dengan rerata produksi sebesar $295,2 \mathrm{~kg}$. g. Pasca Panen

Buah cabe rawit merah yang dipetik disimpan pada tempat yang kering dan sejuk. Sebagian besar cabe rawit merah dijual di pasar-pasar terdekat untuk memenuhi kebutuhan keluarga, biaya anak sekolah, urusan sosial dan ada yang dikonsumsi. Petani menggunakan tenaga kerja dalam keluarga yang berjumlah 30 orang dengan curahan kerja sebesar $30 \mathrm{HKO}$ dengan rerata $2 \mathrm{HKO}$.

\subsection{Analisis Cobb-Douglass}

Analisis yang digunakan adalah analisis regresi berganda dalam bentuk logaritma dengan fungsi produksi Cobb-Douglass. Hasil analisis ditampilkan pada Tabel 1 .

$\underline{\text { Tabel 1. Analisis Varians }}$

\begin{tabular}{cccccc}
\hline \multirow{2}{*}{ Model } & \multicolumn{2}{c}{$\begin{array}{l}\text { Unstandardized } \\
\text { Coefficients }\end{array}$} & $\begin{array}{c}\text { Standardized } \\
\text { Coefficients }\end{array}$ & t-hitung & \multirow{2}{*}{ Sig. } \\
\cline { 2 - 3 } & B & Std. Error & Beta & & \\
\hline (Constant) & 3,941 & 1,968 & & 0,660 & 0,050 \\
X1 & 0,078 & 0,460 & 0,035 & 0,169 & 0,301 \\
X2 & 0,179 & 0,174 & 0,021 & 1,003 & 0,332 \\
X3 & $-0,045$ & 0,054 & $-0,191$ & $-0,827$ & 0,030 \\
X4 & 0,163 & 0,084 & 0,461 & 0,948 & 0,008 \\
X5 & 0,022 & 0,056 & 0,089 & 0,393 & 0,004 \\
X6 & 0,291 & 0,180 & 1,591 & 1,621 & 0,044 \\
\hline
\end{tabular}

Hasil analisis data diperoleh persamaan regresi yang merupakan nilai koefisien dari setiap variabel bebas yakni $\mathrm{LnY}=\mathrm{Ln3}, 941+0,078 \mathrm{LnX}_{1}+$ $0,179 \operatorname{LnX}_{2}-0,045 \operatorname{LnX}_{3}+0,163 \operatorname{LnX} X_{4}+0,022 \operatorname{LnX}_{5}+0,291 \operatorname{LnX} X_{6}+$ e. Uji kelayakan model analisis cobb-douglass dalam menjelaskan produksi cabe rawit merah diketahui dari $\mathrm{R}^{2}$, uji $\mathrm{F}$ dan uji t dengan uraikan sebagai berikut:

a. Koefisien Determinasi $\left(\mathrm{R}^{2}\right)$

Koefisien determinasi menunjukkan seberapa besar hubungan antara variabel bebas dengan variabel terikat. Berdasarkan Tabel 2. diketahui bahwa koefisien determinasi $\left(\mathrm{R}^{2}\right)$ memiliki nilai 0,710 tetapi menurut (Santoso, 2013) bahwa untuk regresi dengan lebih dari dua variabel bebas digunakan Adjusted $\mathrm{R}$ Square sebagai koefisien determinasi sehingga digunakan nilai Adjusted $\mathrm{R}$ Square sebesar 0,492 yang dimana kontribusi modal $\left(\mathrm{X}_{1}\right)$, luas lahan $\left(\mathrm{X}_{2}\right)$, tenaga kerja $\left(\mathrm{X}_{3}\right)$, pengalaman usahatani $\left(\mathrm{X}_{4}\right)$, pendidikan petani $\left(\mathrm{X}_{5}\right)$, dan pupuk kandang $\left(X_{6}\right)$ memiliki pengaruh sebesar $49,2 \%$ terhadap peningkatan maupun penurunan produksi sedangkan sisanya sebesar $50,8 \%$ dijelaskan oleh faktor lain di luar faktor yang diteliti. Kontribusi cukup rendah diduga karena dalam berusahatani cabe rawit merah ternyata petani juga menggunakan pupuk NPK yang tidak diperhitungkan sebagai variabel dalam penelitian ini.

\section{Tabel 2. Koefisien Determinasi $\left(\mathrm{R}^{2}\right)$}

\begin{tabular}{ccccc}
\hline Model & $\mathrm{R}$ & R Square & $\begin{array}{c}\text { Adjusted R } \\
\text { Square }\end{array}$ & $\begin{array}{c}\text { Std. Error } \\
\text { Estimasi }\end{array}$ \\
\hline 1 & 0,842 & 0,710 & 0,492 & 0,03796 \\
\hline
\end{tabular}

\section{b. Pengaruh Secara Simultan}

Uji F dilakukan untuk mengetahui secara bersama faktor-faktor yang mempengaruhi produksi cabe rawit merah. Berdasarkan data pada Tabel 3. dapat dijelaskan bahwa nilai probabilitas $<0,001$ sehingga uji F nyata pada $\alpha 1 \%(0,01)$ dengan demikian dapat dikatakan bahwa variabel bebas yang meliputi modal $\left(\mathrm{X}_{1}\right)$ luas lahan $\left(\mathrm{X}_{2}\right)$, tenaga kerja $\left.\mathrm{X}_{3}\right)$, pengalaman usahatani $\left(\mathrm{X}_{4}\right)$, pendidikan petani $\left(\mathrm{X}_{5}\right)$, dan pupuk kandang $\left(\mathrm{X}_{6}\right)$ bersama-sama memiliki pengaruh nyata terhadap produksi cabe rawit merah.

\begin{tabular}{lccccc}
\multicolumn{2}{l}{ Tabel 3. Analisis $\mathrm{F}_{\text {hitung }}$} \\
\hline \multirow{2}{*}{ Model } & Jumlah & Jumlah & Df & $F_{\text {hitung }}$ & Sig \\
& Kuadrat & Rerata & & 0,000 \\
\hline Regression & 0,028 & 0,003 & 6 & 1,259 & 0 \\
Residual & 0,012 & 0,001 & 8 & & \\
\hline Total & 0,040 & & 14 & & \\
\hline
\end{tabular}

\section{c. Pengaruh Secara Parsial}

Berdasarkan data pada Tabel 1. maka pengaruh secara parsial dari faktor modal $\left(\mathrm{X}_{1}\right)$ luas lahan $\left(\mathrm{X}_{2}\right)$, tenaga kerja $\left(\mathrm{X}_{3}\right)$, pengalaman usahatani $\left(\mathrm{X}_{4}\right)$ pendidikan petani $\left(\mathrm{X}_{5}\right)$, pupuk kandang $\left(\mathrm{X}_{6}\right)$ terhadap produksi cabe rawit merah diuraikan sebagai berikut:

- Modal $\left(\mathrm{X}_{1}\right)$

Modal dalam penelitian ini adalah besarnya modal yang digunakan oleh petani dalam berusahatani cabe rawit merah. Berdasarkan hasil analisis modal tidak berpengaruh nyata terhadap produksi cabe rawit merah. Hasil analisis data diperoleh nilai koefisien regresi untuk variabel modal $\left(\mathrm{X}_{1}\right)$ sebesar 0,078 . Nilai probabilitas modal $\left(\mathrm{X}_{1}\right)$ sebesar $0,301>0,05(\alpha 5 \%)$, sehingga variabel modal tidak berpengaruh terhadap produksi cabe rawit merah. Modal tidak berpengaruh terhadap produksi cabe rawit merah karena petani tidak menggunakan modal secara efisien terutama pembelian benih, pupuk dan pestisida.

- Luas Lahan $\left(\mathrm{X}_{2}\right)$

Luas lahan dalam penelitian ini adalah besarnya luas lahan yang digunakan oleh petani dalam berusahatani cabe rawit merah. Berdasarkan hasil analisis luas lahan tidak berpengaruh nyata terhadap produksi cabe rawit merah. Hasil analisis 
data diperoleh nilai koefisien regresi untuk variabel luas lahan $\left(\mathrm{X}_{2}\right)$ sebesar 0,179 . Nilai probabilitas luas lahan $\left(X_{2}\right)$ sebesar $0,332>0,05(\alpha 5 \%)$, sehingga variabel luas lahan tidak berpengaruh terhadap produksi cabe rawit merah. Alasannya karena petani yang mengusahakan cabe rawit merah dengan luas lahan yang relatif sama (berukuran kecil 9-25 are).

- Tenaga Kerja $\left(\mathrm{X}_{3}\right)$

Tenaga kerja dalam penelitian ini dihitung dalam HKO dan tenaga kerja berasal dari dalam keluarga responden itu sendiri, sehingga tenaga kerja tidak diupah. Hasil penelitian menunjukkan bahwa serapan tenaga kerja cukup banyak pada kegiatan pemeliharaan, petani memfokuskan pada tahap pertumbuhan tanaman dengan mengurangi kompetisi unsur hara antara tanaman cabe rawit merah dan gulma yang tumbuh. Kegiatan pemeliharaan dilakukan pada dua tahap sehingga membutuhkan curahan tenaga kerja yang cukup banyak. Hasil analisis tenaga kerja sangat berpengaruh positif dan sangat nyata terhadap produksi cabe rawit merah. Hasil analisis data diperoleh nilai t untuk variabel tenaga kerja $\left(\mathrm{X}_{3}\right)$ sebesar -0,045. Nilai probabilitas tenaga kerja $\left(X_{3}\right)$ sebesar $0,030<0,05(\alpha 5 \%)$, sehingga variabel tenaga kerja nyata berpengaruh terhadap produksi cabe rawit merah. Tenaga kerja berpengaruh nyata dengan koefisien regresi sebesar $-0,045$ menunjukkan bahwa setiap adanya penambahan tenaga kerja sebesar $1 \%$ akan mengurangi produksi sebesar $0,045 \%$. Kondisi ini terjadi karena adanya pemborosan penggunaan tenaga kerja. Semakin banyak tenaga kerja yang digunakan pada tahap tertentu usahatani akan menyebabkan tenaga kerja tersebut menggunakan waktu dan tenaga secara tidak efisien.

- Pengalaman Usahatani $\left(\mathrm{X}_{4}\right)$

Pengalaman yang dimaksudkan dalam penelitian ini adalah pengalaman responden dalam berusahatani cabe rawit merah. Berdasarkan hasil analisis pengalaman usahatani berpengaruh secara nyata terhadap produksi cabe rawit merah. Hasil analisis data diperoleh nilai koefisien regresi untuk variabel pengalaman usahatani $\left(\mathrm{X}_{4}\right)$ sebesar 0,163 . Nilai probabilitas pengalaman usahatani $\left(\mathrm{X}_{4}\right)$ sebesar $0,008<0,01(\alpha 1 \%)$, sehingga variabel pengalaman usahatani berpengaruh terhadap produksi cabe rawit merah. Pengalaman usahatani berpengaruh nyata dengan koefisien regresi sebesar 0,163 menunjukkan bahwa setiap adanya penambahan pengalaman usahatani sebesar $1 \%$ akan menambah produksi sebesar $0,163 \%$, dengan asumsi variabel lain dianggap tetap. Alasannya karena dalam mengusahakan cabe rawit merah membutuhkan keterampilan khusus sehingga petani yang berpengalaman akan menerapkan usahatani yang baik (misalnya : penyiangan tepat waktu, pemupukan dengan dosis yang tepat dan pengendalian hama penyakit dengan pestisida yang tepat sasaran), sehingga akan memperoleh produksi yang lebih tinggi.

- Pendidikan $\left(\mathrm{X}_{5}\right)$

Pendidikan yang dimaksudkan dalam penelitian ini adalah pendidikan yang ditempuh oleh petani mulai dari jenjang SD hingga SMA yang disertai dengan mengikuti pelatihan. Hasil analisis data diperoleh nilai $t$ untuk variabel pendidikan $\left(\mathrm{X}_{5}\right)$ sebesar 0,022 . Nilai probabilitas pendidikan $\left(\mathrm{X}_{5}\right)$ sebesar 0,004 $<0,01(\alpha 1 \%)$, sehingga variabel pendidikan berpengaruh nyata terhadap produksi cabe rawit merah. Pendidikan berpengaruh nyata dengan koefisien regresi sebesar 0,022 menunjukkan bahwa setiap adanya penambahan pendidikan sebesar $1 \%$ akan menambah produksi sebesar $0,022 \%$ dengan asumsi variabel lain dianggap tetap. Alasannya karena petani dengan pendidikan yang lebih tinggi akan lebih mudah melakukan adopsi inovasi teknologi pertanian khususnya yang berkaitan dengan usahatani cabe rawit merah.

- Pupuk Kandang $\left(\mathrm{X}_{6}\right)$

Pupuk kandang dalam penelitian ini adalah besarnya pupuk kandang yang digunakan petani dalam satu kali musim tanam. Berdasarkan hasil analisis pupuk kandang berpengaruh secara nyata terhadap produksi cabe rawit merah. Hasil analisis data diperoleh nilai koefisien regresi untuk variabel pupuk kandang $\left(\mathrm{X}_{6}\right)$ sebesar 0,291. Nilai probabilitas pupuk kandang $\left(\mathrm{X}_{6}\right)$ sebesar $0,044<0,05(\alpha$ $5 \%$ ), sehingga variabel pupuk kandang berpengaruh nyata terhadap produksi cabe rawit merah. Pupuk kandang berpengaruh nyata dengan koefisien regresi sebesar 0,291 menunjukkan bahwa setiap adanya penambahan pupuk kandang sebesar $1 \%$ akan menambah produksi cabe rawit merah sebesar $0,291 \%$ dengan asumsi variabel lain dianggap tetap. Alasannya karena dalam mengusahakan cabe rawit merah dibutuhkan pupuk kandang untuk merangsang pertumbuhan dan perkembangan cabe rawit merah.

\subsection{BEP (Break Event Point)}

Modal sebagai salah satu faktor yang dianalisis dalam penelitian ini. Biaya tetap meliputi biaya pembelian linggis, parang, tajak, ember, sekop, dan pacul. Biaya variabel meliputi pembelian benih, pupuk dan pestisida. Berdasarkan hasil penelitian total modal yang digunakan sebesar Rp5.530.667,00. Total modal tersebut digunakan untuk biaya tetap sebesar Rp2.923.667,00 dan biaya variabel sebesar Rp2.607.000,00. Informasi lain yang diperoleh adalah produksi cabe rawit merah $4.428 \mathrm{~kg}$, penjualan $\mathrm{Rp} 265.680 .000,00$, biaya variabel per unit Rp588,75, dan harga jual per kilogram Rp. 60.000,00. Informasi dalam usahatani cabe rawit merah ini digunakan untuk analisis BEP.

Berdasarkan hasil analisis diketahui bahwa BEP rupiah usahatani cabe rawit merah sebesar Rp2.952.602,00 artinya petani harus menjual cabe rawit merah lebih besar dari Rp2.952.602,00 sehingga menguntungkan bagi petani di desa Tapenpah. BEP unit sebesar $49 \mathrm{~kg}$ artinya petani harus memproduksi cabe rawit merah lebih besar dari $49 \mathrm{~kg}$ setiap musim tanam. Penelitian ini menunjukkan bahwa total produksi cabe rawit merah di desa Tapenpah sebanyak $4.428 \mathrm{~kg}$ dengan rerata produksi sebesar $295,2 \mathrm{~kg}$.

\section{Simpulan}

Usahatani cabe rawit merah di desa Tapenpah dilakukan secara monokultur dengan luas lahan yang berbeda-beda berkisar antara 9-25 are. Usahatani dilakukan dengan tahapan 1) persiapan berupa pembersihan lahan; 2) pengolahan lahan dengan cara tanah dicangkul atau dibajak; 3) benih cabe rawit merah disemaikan setelah itu disiram dengan air; 4) penanaman dilakukan setelah bibit berumur 21 hari dengan kriteria memiliki 3-4 helai daun; 5) pemeliharaan meliputi penyiraman, penyiangan, pemupukan dan pengendalian hama penyakit; 6) panen pada usia 3-4 bulan; dan 7) buah cabe rawit merah disimpan pada tempat yang kering dan sejuk, kemudian cabe rawit merah dijual di pasar-pasar terdekat. Faktor modal, luas lahan, tenaga kerja, pengalaman usahatani, pendidikan petani, dan pupuk kandang secara bersama-sama berpengaruh nyata terhadap produksi cabe rawit merah. Secara parsial faktor pengalaman usahatani, pendidikan petan dan pupuk kandang memiliki pengaruh yang positif, faktor tenaga kerja berpengaruh negatif dan signifikan terhadap produksi usahatani cabe rawit merah. Sedangkan modal dan luas lahan tidak berpengaruh terhadap produksi usahatani cabe rawit merah. Biaya produksi usahatani cabe rawit merah dalam satu kali musim tanam Rp5.530.667,00 dengan harga jual ditingkat petani sebesar Rp60.000,00 per kilogram sehingga BEP rupiah sebesar Rp2.952.602,00 dan BEP unit sebesar $49 \mathrm{~kg}$.

\section{Pustaka}

Ajak, A. \& Taolin, R.I. 2016. Pengaruh Olah Tanah dan Jenis Pupuk Kandang terhadap Pertumbuhan dan Hasil Cabe Rawit Varietas Bara (Capsicum frutescens L.). Savana Cendana, 1(03): 98-101.

Alwi, S. 1994. Alat-Alat Analisis dalam Pembelanjaan. Revisi ed. Yogyakarta: Andi Offset.

BPS Kab. TTU 2016. Kabupaten Timor Tengah Utara dalam Angka 2016. Kefamenanu: Badan Pusat Statistik Kabupaten TTU.

De Araujo, M. \& Nubatonis, A. 2016. Analisis Produksi dan Pemasaran Usahatani Padi Sawah di Desa Tualene Kecamatan Biboki Utara Kabupaten Timor Tengah Utara. AGRIMOR, 1(03): 55-56.

Falo, M., Kune, S.J., Hutapea, A.N. \& Kapitan, O.B. 2016. Faktor-Faktor yang Mempengaruhi Produksi dan Strategi Pengembangan Usahatani Bawang Putih di Kecamatan Miomaffo Barat, Kabupaten Timor Tengah Utara. AGRIMOR, 1(04): 84-87.

Gujarati, D.N. \& Porter, D.C. 2009. Basic Econometrics. McGraw-Hill Irwin.

Haki, M.G. \& Taena, W. 2017. Analisis Pendapatan Usahatani Cabe Rawit Merah di Desa Tapenpah Kecamatan Insana Kabupaten Timor Tengah Utara. AGRIMOR, 2(04): 57-58.

Hoar, E. \& Fallo, Y.M. 2017. Pengaruh Faktor Sosial Ekonomi Petani terhadap Produksi Usahatani Jagung di Desa Badarai Kecamatan Wewiku Kabupaten Malaka. AGRIMOR, 2(03): 36-38

Neonbota, S.L. \& Kune, S.J. 2016. Faktor-Faktor yang Mempengaruhi Usahatani Padi Sawah di Desa Haekto, Kecamatan Noemuti Timur. AGRIMOR, 1(03): 32-35.

Santoso, S. 2008. Panduan Lengkap Menguasai Spss 16. Jakarta: Elex Media Komputindo.

Santoso, S. 2013. Menguasai SPSS 21 di Era Informasi. Jakarta: Elex Media Komputindo.

Setiadi 2006. Bertanam Cabai. Jakarta: Penebar Swadaya.

Sugiyono 2006. Metode Penelitian Kuantitatif, Kualitatif dan $R \&$ D. Bandung: Alfabeta.

Usboko, A.M. \& Fallo, Y.M. 2016. Faktor Sosial Ekonomi yang Mempengaruhi Produksi Usahatani Sayuran Sawi di Kelompok Tani Mitra Timor. AGRIMOR, 1(03): 60-62. 